\title{
Narrative, Nature, Society: The Network of Waste in Andrés Neuman's Bariloche
}

\begin{abstract}
Refuse is a key theme, image and structural device in the Spanish-Argentine writer Andrés Neuman's novel Bariloche (1999), whose protagonist is a waste collector in Buenos Aires. My contention, though, is that waste not only fulfils a narrative function, but in fact constitutes what Bruno Latour terms a 'network', a web of interactions between discursive, natural and social processes. Bringing together close literary analysis with insights from environmental criticism (Stacy Alaimo and Jane Bennett) and sociology (Zygmunt Bauman and Martin O'Brien), this paper reveals the complex interactions between the human and non-human world in the novel's urban setting.
\end{abstract}

\section{Introduction}

Environmental criticism, or ecocriticism, is an emerging area of research that has gained renewed vigour over the last two decades, particularly since the Association for the Study of Literature and Environment was set up in the United States in 1992. No longer dedicated to a specific, limited body of texts (namely, nature writing), it is now a vibrant research field that encompasses a large variety of 'earth-centred' approaches to literary and cultural materials from different disciplinary angles from philosophy, history and sociology to ecology, biology and physics. As a relatively young field, though, it is still seeing vast new territories being opened for investigation and exploration. Among these is the representation of the relationship between man and urban environments. As Kevin Hutchings argues, 
'ecocriticism runs the risk of ignoring, to its detriment, the inescapable interpenetration of urban and exurban, or human and non-human, realities and [concerns'. ${ }^{1}$ He echoes Lawrence Buell's concern that the prefix 'eco' is generally associated with "the "natural" rather than the "built" environment'. 'Rather than' is emphasized by Buell in order to highlight the misconception that the 'natural' and the 'built' are mutually exclusive, rather than deeply intertwined, categories. As Kathleen Wallace and Karla Armbruster have argued, 'a viable ecocriticism must continue to challenge dualist thinking by exploring the role of nature in texts more concerned with human culture' ${ }^{3}$

In what follows, I will examine the interconnections between the human and the non-human, the social and the natural, the urban and the exurban in the SpanishArgentine writer Andrés Neuman's first novel, Bariloche (1999). ${ }^{4}$ In this prize-

${ }^{1}$ Kevin Hutchings, 'Ecocriticism in British Romantic Studies', Literature Compass, 4 (2007), 172-202, (p. 174).

${ }^{2}$ Lawrence Buell, The Future of Environmental Criticism: Environmental Crisis and Literary Imagination (Malden, MA; Oxford: John Wiley \& Sons, 2009), p. 12.

${ }^{3}$ Karla Armbruster and Kathleen R. Wallace, Beyond Nature Writing: Expanding the Boundaries of Ecocriticism (Charlottesville: University of Virginia Press, 2001), p. 4. ${ }^{4}$ Apart from a handful of journalistic and academic reviews, only one study - an MA thesis by Vladimir Ricardo Poveda Rangel - has been dedicated to the novel. In his sociological reading of the novel, Poveda Rangel analyses the social, and particularly sexual, relationships in the novel, situating them in a postmodern context, particularly in terms of Zygmunt Bauman's notion of 'liquid love'. See Vladimir Ricardo Poveda 
winning novel, the brief chapters or fragments alternate between the protagonist's present as a waste collector in Buenos Aires and his past as a child growing up in Bariloche, which he reconstructs idealistically through jigsaw puzzles. My focus will be on the representations of waste in the text, the different processes in which it is entangled, and the different levels on which operates: natural and bodily, narrative and structural, social and political.

This paper thus locates itself at the forefront of what is regarded by Lawrence Buell as 'second-wave ecocriticism', which 'has so far concentrated strongly [...] on locating vestiges of nature within cities and/or exposing crimes of eco-injustice against society's marginal groups' ${ }^{5}$ With regards to the former, I will demonstrate that Neuman's novel does not simply point to 'vestiges' of nature within Buenos Aires, but rather problematizes the straightforward distinction between natural and urban. The narrative foregrounds the bio-chemical processes involved in the ejection and decomposition of (urban) waste. In addition, the waste of the city produces its own ecosystem, becoming a habitat for cats, rats, mice, as well as human scavengers. Nature, more than a 'vestige' - a remainder or reminder of the irrecoverable past or the remote Bariloche - is an intervening force, a reality that acts upon Buenos Aires' dwellers.

With regards to the latter, I will identify a narrative of eco-injustice that underpins the novel, summarized by Neuman's own depiction of our 'condición

Rangel, 'El individualismo narcisista de la sociedad posmoral en la narrativa de Andrés Neuman' (MA thesis, 2011).

${ }^{5}$ Buell, The Future of Environmental Criticism, p. 24. 
ciudadana': 'unos producimos mierda sabiendo que otros cargarán con ella' ${ }^{6}$ The novel, as we shall see, is driven by a political message, a critique of a social structure in which those who produce most waste are those who are most distanced from it, both physically and socially. Broadening this argument out, I will argue that Neuman paints a vivid picture of what Zygmunt Bauman terms 'wasted lives', the outcasts from the project of modernization and progress, whether the unemployed, the migrant or the refugee. ${ }^{7}$ By connecting certain characters - the 'lowly' workers Demetrio and El Negro, and the old tramp known as 'el viejo de Tacuarí' - directly with the waste with which they come into contact, Neuman's novel adumbrates and literalizes Bauman's metaphor, raising important social issues connected with man's relationship with his/her material environment.

A key theoretical strand underpinning my argument will be the notion of the 'proliferation of hybrids' put forward by the anthropologist of science Bruno Latour, whose ideas have informed the recent 'material turn' in ecocriticism headed by scholars like Stacy Alaimo, Jane Bennett and Karen Barad. For Latour, the tendency to separate scientific, sociological and textual phenomena prevents us from understanding the nature/culture hybrids by which we are surrounded and in which we are inevitably, and often unwittingly, entangled. As he puts it, 'the ozone hole is too

\footnotetext{
${ }^{6}$ Andrés Neuman, 'Basura, lengua y fragmentos: a propósito de Bariloche', piedepágina. Revista de libros 12 (August 2007). Available at <http://www.piedepagina.com/numero12/html/andres_neuman.html> (consulted 17 January 2015).

${ }^{7}$ Zygmunt Bauman, Wasted Lives: Modernity and Its Outcasts (Oxford; Malden, MA: Polity Press, 2003).
} 
social and too narrated to be truly natural; the strategy of industrial firms and heads of state is too full of chemical reactions to be reduced to power and interest; the discourse of the ecosphere is too real and too social to boil down to meaning effects. ${ }^{8}$ Rather than fitting into distinct ontological categories of human/nonhuman, social/natural, so-called modern phenomena in fact constitute 'networks' in which different strands interact with one another in mutual relationships of exchange and negotiation, which Latour terms 'translation'. 'Networks,' as he puts it, are 'simultaneously real, like nature, narrated, like discourse, and collective, like society'. ${ }^{9}$ As such, they require modes of analysis that can engage with all of these aspects, which correspond with three traditionally separate disciplinary areas: the natural sciences, the humanities, and the social sciences. One of the most significant implications of his theory is that it raises the standing of the non-human world, whose beings and materials are endowed with the capacity to produce effects and transformations as 'actants, acting agents, interveners' ${ }^{10}$

In the ecocritical context, Dana Phillips praises Bruno Latour's reflections on the hybridization of nature and culture, regarding his argument as a useful means of

\footnotetext{
${ }^{8}$ Bruno Latour, We Have Never Been Modern (Cambridge, MA: Harvard University Press, 1993), p. 6.

${ }^{9}$ Ibid.

${ }^{10}$ Bruno Latour, Politics of Nature: How to Bring the Sciences into Democracy (Cambridge, Mass: Harvard University Press, 2004), p. 75.
} 
resisting ecocriticism's dualistic tendencies. ${ }^{11}$ In the more specific context of an Ethics of Waste, Gay Hawkins asks the following pertinent question: 'could we think of waste as evidence of translation, as part of this proliferation of hybrids?'12 By way of example, he gives 'the abandoned car body rotting quietly in the landscape, [which] is alive with activity of corrosion, it's become a habitat, it looks perfectly at home, it's both organic and machinic'. ${ }^{13}$ Though he does not expand on this idea, the implication is that waste might be considered a 'network' in the same way that Latour views the hole in the ozone layer, the discourse of the ecosphere or the business strategies employed by businessmen and politicians. In what follows, I shall pursue this intriguing idea, suggesting that waste as it is presented in Bariloche lies at the intersection of the three categories identified by Latour: nature, discourse and society. In order to delve into these three different areas, I shall bring together literary analysis with insights from environmental critics (Stacy Alaimo and Jane Bennett) and sociologists (Zygmunt Bauman and Martin O’Brien). Firstly, I will consider the ways in which its material properties are brought to the fore throughout the narrative, connecting the 'body' of waste to human and animal bodies. In my analysis, I will invoke Stacy Alaimo's notion of 'trans-corporeality', which (following insights from the likes of Latour) challenges the human/nonhuman divide by analysing the 'many

${ }^{11}$ Dana Phillips, The Truth of Ecology: Nature, Culture, and Literature in America: Nature, Culture, Literature in America (Oxford ; New York: Oxford University Press, 2003), pp. 30-34.

${ }^{12}$ Gay Hawkins, The Ethics of Waste: How We Relate to Rubbish (Rowman \& Littlefield, 2006), p. 10.

${ }^{13}$ Ibid. 
interfaces between human body and the larger environment,' and disturbs our notion of the human self by forcing us to recognise that " "the environment" is not located somewhere out there, but is always the very substance of ourselves'. ${ }^{14}$ Secondly, I will examine how waste is narrativized, contributing to the weft of present experience and past memories that paradoxically drive the narrative forward. As we shall see, the narrative yarns spun from discarded objects bring the reader into the naturalconstructed world of Bariloche, and thus activate these memories/fantasies. Lastly, I will argue that the link between humans and waste - or their attempted, delusory polarization - raises political and social issues that underlie the novel. In this vein, the characters of scavengers and waste collectors are situated in the context of the "wasted lives' that according to Bauman have been produced by modernity.

These three interconnected layers in turn open up three, similarly interwoven, readings of the ending of the novel, the strange, ambiguous communion of Demetrio with the rubbish dump which suggestively culminates in his suicide: the decided dissolution of the barriers between the human body and the 'body' of waste; the final blending of the two narratives that correspond to the two landscapes of the novel, Buenos Aires and Bariloche; and the grotesque transformation of the human into a waste product, the literalization of Bauman's 'wasted lives'.

\section{'Real, like Nature': The (Trans-)corporeality of Waste}

The exclusion of the urban environment from ecocritical commentary is based on a false opposition between rural and urban, natural and man-made, non-human and

\footnotetext{
${ }^{14}$ Stacy Alaimo, Bodily Natures: Science, Environment, and the Material Self (Indiana University Press, 2010), p. 4.
} 
human which are dismantled in Neuman's novel. As Demetrio walks through the 'oasis' of Lezama Park in Buenos Aires, he steps on 'las hojas y la tierra', and walks past a disused railway line, 'cubierta por la hierba'; later in the novel, on the corners and window ledges of a ruined, ramshackle house 'crecían, absurdos, unos puñados de hierba de un excelente verde'. ${ }^{15}$ Nature is shown to thrive at the heart of the city, and to reclaim certain built-up spaces. My contention is that it is the material of waste that most powerfully blurs these boundaries throughout the novel. Unsurprisingly, the accumulation of rubbish in Bariloche is connected to the vast scale of Buenos Aires, to the urban environment of the mega-city. Though every culture has produced waste, the modern metropolis produces it on a different scale. As Catherine Alexander and Joshua Reno suggest, 'the large-scale production of waste that cannot be reabsorbed by domestic or agricultural practices, and thus must be systematically collected and disposed of, is a phenomenon of urbanization'. ${ }^{16}$ The immense scale of the rubbish produced in the sprawling city is captured through the eyes of Demetrio, who sees the rubbish dump as a mountain (pp. 103, 132), a 'colosal hoyo mugriento' (p. 109) and a monster (p. 167), and asks himself 'cómo podía haber tanta, tanta mierda' (p. 166). Importantly, though, these images link the magnitude of the waste not so much with

\footnotetext{
${ }^{15}$ Andrés Neuman, Bariloche (Barcelona: Anagrama, 2007), pp. 50, 157. Hereafter, all references to this edition will be made within the body of the text.

${ }^{16}$ Catherine Alexander and Joshua Reno, Economies of Recycling: Global Transformations of Materials, Values and Social Relations (London; New York: Zed Books, 2012), p. 6.
} 
the urban environment, but with natural landscapes and processes: mountains, dirt and shit. ${ }^{17}$

Indeed, waste is depicted in Bariloche in all its materiality and physicality, as a living, moving entity animated by biological and chemical processes. By weaving the 'body' of waste with human and animal bodies through the action and images of the narrative, Neuman hints at what Alaimo terms 'trans-corporeality' - the 'material interconnections of human corporeality with the more-than-human world', the 'movement across human corporeality and nonhuman nature'. ${ }^{18}$ In what follows, I shall examine the ways in which the waste is constructed as a body, which in turn is connected with the bodies of the humans and animals that coexist with it. The main character at the centre of the narrative cannot be separated from the more-than-human protagonist: the waste that he both produces and collects and the dump where he finally meets his death.

The novel opens thus:

${ }^{17}$ The materiality of excrement and dirt as presented by Neuman are reminiscent of César Vallejo's Trilce 1 (1922), a poem that pays tribute to the Peruvian guano islands, where bird shit - 'la simple calabrina tesórea' - was 'discovered' as a lucrative resource. In that poem (as in the rest of the Trilce collection), Vallejo foregrounds, and revels in, the irreducibility of material, bodily substances. César Vallejo, Trilce, in The Complete Poetry of César Vallejo. A Bilingual Edition (Berkeley and Los Angeles: University of California Press, 2007), p. 166. ${ }^{18}$ Alaimo, pp. 2-3. 
Eran las cuatro en punto cuando Demetrio Rota iluminó débilmente la noche con su traje fluorescente. Casi sin pensarlo, dejó caer un escupitajo en una alcantarilla. Se complació en acertar. La húmeda vaharada del Río de la Plata llegaba desde el puerto y atravesaba Paseo Colón hasta llegar a la 9 de Julio; a partir de allí, el aliento invernal de Buenos Aires capaba a sus anchas: espeso, continuado, corrosivo. El frío era lo de menos. [...] Junto al camión, que despedía un hedor cálido a motor y residuos, a cáscaras de naranja, yerba mate usada y gasolina, él y su compañero tiritaban con esquimal indiferencia. (p. 15)

Immediately, the reader is presented with a series of exchanges between the human body and the more-than-human environment. Demetrio lights up the night with his fluorescent jacket and spits into the gutter in an almost automatic physical (re)action, whilst the cold causes him and his workmate to shiver - a bodily function that helps warm-blooded animals maintain homeostasis. The air is heated up both by the lorry's motor and the heat generated by the waste through the action of decomposition. The non-human residues - the orange peel, the mate tea leaves, and the petrol fumes - are connected with the human body: on a narrative level, these residues echo the saliva that Demetrio ejects from his mouth; on a physical level, the waste collectors' bodies internalize the waste through the sensory perception of smell, the 'hedor cálido'. The smell of the River Plate (generated by industrial, agrochemical and household refuse) is presented as a living entity, which moves through the city like a human character: it 'arrives' from the port and 'crosses' Paseo Colón until it 'reaches' 9 de Julio Avenue. The word 'vaharada', though, not only means smell or stench, but also a puff of breath, a metaphor extended through the image of the 'aliento invernal de Buenos 
Aires'. Neuman thus creates a link between air pollution (man-made but involved in natural, bio-chemical processes, as suggested by the adjective 'corrosive') and the human body (in this case, the action of breathing and the organ of the lungs), hinting at the trans-corporeal movements of toxins between the urban environment and human organisms. Demetrio's surname, Rota, might be significant in this context: his body, his name suggests, is 'broken', like the rubbish that he collects; his back is bent by the weight of the rubbish; his lungs and bloodstream are invaded by noxious petrol fumes; his physical being is trans-corporeally connected to urban waste.

Later on, the torrential rain leads the waste to invade not only the air, but also the water: 'el plástico de las bolsas sudaba, cedía al aire una parte de su hedor y terminaba por disolverse en el fino torrente que corría por las alcantarillas de la calle Piedras' (p. 62). The bin bags characteristically take the form of living bodies as the plastic 'sweats', suggesting not only the release of a stench of rotting debris through chemical reactions, but also a human/animal biological process. Escaping through the holes (or pores) of the bag, the waste joins with and dissolves into the stream that runs through the gutter, which in turn connects it with the spit that Demetrio ejected into the gutter in the opening scene. Indeed, the urban landscape is presented as an ecosystem that brings together the bodies of waste, animals and humans:

A través de un agujero desgarrado con el método de las bestias, pudieron ver las húmedas entrañas de una bolsa, y un segundo después emergió de un brinco otra tensa silueta que se unió a la primera, para alejarse con ella, entre juegos, como dos marionetas alucinadas. Demetrio sintió un escalofrío. (p. 42) 
Three bodies are brought together in this passage: the 'body' of the bin bag, whose plastic skin covers its humid entrails; the bodies of the animals (rats, mice or cats) that have clawed into the bin liners to feed off the refuse; and Demetrio's body that responds to the scene with a shudder. The shudder of disgust is ambiguous. For the character, it could be caused by the sight of the rats or by the stench or sight of the rubbish. For the reader, though, it might be produced by the discomforting realization of the connectedness of the human and more-than-human world. Barriers between human artifice and nonhuman nature are further dissolved as the animals are presented as puppets that perform an artistic play of shadows.

The image of waste as a body with skin, a mouth, a throat, and digestive organs is a recurring one throughout the novel, serving at once to foreground its biological, chemical processes and to connect it with the animal/human. The rubbish dump at the end of Demetrio's and El Negro's daily journey is frequently referred to as a huge devouring beast: 'avanzaron hasta el gran abismo vallado para descargar los cientos de kilos de desperdicios que apenas si podrían calmar la voracidad de la garganta hedionda' (p. 29); 'se le ocurrió imaginar que la mole, una vez digerido su banquete hediondo, excretaba las sobras hacia el corazón de la ciudad, y de allí partían diseminadas a los hogares y a los contenedores de las calles que más tarde volverían a alimentar el basurero, una y otra vez' (p. 103). Here, the fetid dump is portrayed not as a passive recipient of waste, but as an active consumer with an insatiable appetite. Its abyssal quality suggests a bottomless stomach. Demetrio's fantasy - the image of the rubbish dump digesting its banquet, excreting the residues, and sending them back into households where they would once again be thrown away and sent to feed the dump - is significant for two reasons. Firstly, it hints at the transcorporeality of waste, its transgression of the constructed barrier between the human 
body and the non-human environment, as the rubbish dump not only receives waste produced by humans, but also gives some of it back. Though the cycle is not as literal as in Demetrio's imagination, this image is in fact very close to the actual transactions and interconnections between the human body and the 'body' of waste. As highlighted in this novel, waste is uncontained, overflowing from plastic bags, vehicles and landfill sites in the solid form of its 'entrails', the liquid form of leakages, or the gas form of toxic fumes. It is not contained or containable, but ‘desbordado' (p. 47) - overflowing, invasive and insidious.

Secondly, the rubbish dump is imagined in explicitly human terms, consuming a 'banquet' of residues. This anthropomorphosization occurs elsewhere in the novel: 'por un momento le pareció que el abismo y él se miraban y bostezaban juntos' (p. 47); 'los perros y gatos parecían haberse conjurado aquella noche para descubrir los intestinos del vecindario, su secreta intimidad anudada y vestida de luto' (p. 142). In the first passage, the 'abyss' of the waste dump is endowed with eyes and a mouth. It is depicted not as a passive object or environment, but rather an active subject that looks at Demetrio and yawns, suggesting human feelings of wariness and boredom. In the second, the surprisingly soft, tender and nostalgic image of the garbage as 'secret intimacy' dressed in mourning attributes not only human form to the waste, but also human sentiment (intimacy, privacy, mourning, grief) ${ }^{19}$ On the one hand, the

\footnotetext{
${ }^{19}$ This anthropomorphism echoes that which recurs in the descriptions of Bariloche, which for reasons of space are not discussed in this article: 'las araucarias muestran unos esbeltos dedos' (p. 45); 'el lago era como un gran hermano de agua que me entendía sin pedirme nada' (p. 39); ‘su rostro sin espuma está dormido' (p. 113); 'la faz del cerro López se sorprende decrépita' (p. 138); and so on. These might be
} 
anthropomorphosization of the 'body' of waste in human terms is anthropocentric, revealing an inability to perceive the natural or material world in its own, distinctive complexity. On the other hand, as Jane Bennett suggests, it is capable of catalysing 'a sensibility that finds a world filled not with ontologically distinct categories of beings (subjects and objects) but with variously composed materialities that form confederations'; it can therefore paradoxically work against anthropocentrism as 'a chord is struck between person and things, and I am no longer above or outside a nonhuman "environment",. ${ }^{20}$ In drawing connections between waste materials and human organs, processes and sentiments, Demetrio's narcissistic gaze in fact collapses the ontological divides between the human and the non-human, the active subject and the passive object, and heightens the sense of what Jane Bennett calls the 'vibrancy of matter'.

Certainly, waste is depicted by the narrator not only in terms of the natural processes which it undergoes, whether corrosion, decay, or fermentation, but also in its active, invasive qualities. One example is in fragment XVIII, as Demetrio and El Negro are getting ready for their shift: 'soplaba un aire que agredía a ráfagas. Los desperdicios fermentaban por la noche, y el hedor hacía estremecerse aun a los más habituados' (p. 52). Again, the metabolic process of fermentation in the organic residues releases a stench that produces a physical reaction - a shudder of disgust - in the urban subjects. As suggested by the use of the verb 'agredir', the waste emits

interpreted as instances of the narcissism analysed by Poveda Rangel, but also in terms of the sensibility towards the non-human world described by Bennett.

${ }^{20}$ Jane Bennett, Vibrant Matter: A Political Ecology of Things (Durham: Duke University Press, 2010), pp. 99, 120. 
invasive fumes into the air that possess a powerful, harmful quasi-agency. Similarly, earlier in the novel, the line of bags on the pavement is described as an 'army' (p. 15), suggesting its invasive power and possible violence, which is echoed later in the description of 'la vaharada hostil del Río de la Plata' (p. 141). This aggressive quality might be read in the context of what Nixon terms 'slow violence'. As Nixon points out, violence is generally associated with the sudden, spectacular, eye-catching, explosive event - acts of war, invasions, terrorist attacks, to which governments can respond through fast-response, short-term action. What he calls 'slow violence', on the other hand, is that which 'occurs gradually and out of sight, a violence of delayed destruction that is dispersed across time and space, an attritional violence that is typically not viewed as violence at all'. ${ }^{21}$ Air pollution is a very good example of that, since it is often invisible, but can have a noxious physical effect on human beings. The aggression refers most directly to the smell that 'hits' Demetrio, but also hints at the less immediate effects, like respiratory diseases, cancer and the widespread contamination of certain environments.

This brings me to a first possible reading of the ending of the novel, as the culmination of a process in which the 'body' of waste and the human body are brought together in trans-corporeal relations. In the final scene, as Demetrio approaches the waste dump, 'la mole hedionda [...] también iba a su encuentro' (p. 165). The agency of the detritus as a moving subject recalls the very opening of the novel, where the smell of the contaminated river is depicted in its trajectory through the city. Here, though, it is not the fumes generated by the rubbish but the solid waste

\footnotetext{
${ }^{21}$ Rob Nixon, Slow Violence and the Environmentalism of the Poor (Cambridge, MA: Harvard University Press, 2011), p. 2.
} 
itself that seems to be endowed with the ability to move. The movements across the 'body' of waste and the human body become intensified in Demetrio's final moments on the rubbish heap:

vio la mole en sus detalles, su lomo irregular, su superficie abultada como un bosque de heridos que se revuelven o que ya no se mueven [...] Bajo sus pies [...] respiraba toda la excrecencia del mundo con su aliento venenoso. La vista se le perdía en un horizonte de [...] millones de cabezas asomadas desde la tierra hacia la fría noche, buscando algo de oxígeno. [...] Más que moverse como criaturas individuales, los desperdicios lo hacían con tendencia a fusionarse, era tan uniforme todo, el nylon, la mierda y el silencio... La convulsión provenía de abajo, de muy profundo abajo, él lo intuía bajo sus pies helados, era un temblor verde y subterráneo que tejía una piel artificial e invulnerable, la Mierda Única, un mar de ahogados [...] (pp. 166-7)

Like a dense pile of writhing or motionless injured bodies, with innumerable heads reaching up for a gulp of oxygen, the waste appears to be alive. The 'convulsion', suggesting the regular contraction of muscles, is an intensification of the movements of the rubbish depicted throughout the novel. Anthropomorphism, however, goes beyond the metaphorical: the 'poisonous breath' emitted by the waste points to the passage of pollutant substances from the non-human materials to the human body. Indeed, it is through Demetrio's body (his frozen feet) that the movements are felt, as his skin seems to join with the 'artificial skin' of the bin bags, and his palpitations appear to echo the convulsions that come from below. His death, then, might be interpreted as a grotesque communion with the rubbish dump, as a merging with 'the 
nylon, the shit, the silence'. 'The silence' might be a tongue-in-cheek - or perhaps more sinister - reference to the well-known and oft-quoted ending of Hamlet: 'The rest is silence'. Indeed, the 'rest' is a double reference to the remainder of Hamlet's life, and to the peace of death, reinforced in the idea of 'silence'; it is Hamlet's coming to terms with his own mortality. In the context of Bariloche, though, it might also be interpreted very literally as the 'remainder', the 'residue', the 'rubbish', underlying Demetrio's communion with the 'Mierda Única' as he faces his own death. Through images and literary references, then, the reader witnesses the final dissolution of the gap between the rarefied, self-contained rational human being and the material mess, muck and muddle.

\section{'Narrated, like Discourse': Waste, Memory and Narrative}

Within the narrative, waste materials take on different and sometimes contradictory forms: putrid matter, fetishized objects, means of survival or employment. They unleash feelings of disgust, horror, affection, nostalgia, regret, despair, and so on. Like Martin O'Brien's sociological study, this literary study seeks to tease out 'some of the rich complexity that characterizes contemporary relationships with wastes' by examining a text that demonstrates that 'the relationships that people and organisations have with waste do not consist in a one-dimensional callous disregard'. ${ }^{22}$ This is particularly relevant in the context of the global culture, politics and economics of unofficial recycling that has emerged with particular force since the mid-1990s, when the demand for recycling increased due to a combination of factors

\footnotetext{
${ }^{22}$ Martin O’Brien, A Crisis of Waste? Understanding the Rubbish Society (London: Routledge, 2011), pp. 8, 6.
} 
(the surge in waste production, the pressure on landfill sites, heightened environmental awareness and so on). With informal recycling activities proliferating all over the world, and notably in Latin America, waste pickers' organizations also began to emerge with force. It was in Medellín, Colombia, that the first Latin American informal recycling organization was set up (the Cooperativa Antioqueña de Recolectores de Subproductos). Throughout the 1990s, though, powerful waste pickers' associations began to solidify across Latin America - most notably in Argentina and Brazil. The largest is the independent Movimiento de Trabajadores Excluidos (MTE) in Argentina, which fights against exclusion, exploitation and slavery and seeks to improve working conditions for cartoneros (and costureros). It brings together over 2,000 cartoneros in greater Buenos Aires and has made waves in raising awareness among the locals about the need to separate rubbish to make the job of the waste collector less difficult, time-consuming and hazardous.

Though these activities and socio-political organizations are not directly referred to within the body of Neuman's text, they are certainly part of the Latourian 'network' of waste which comes into play in the novel, and are hinted at in the way in which Demetrio treats - and 'cares for' - both waste items (the rubbish he collects), as will be examined in this section, and the wasted lives (the tramp and child waste picker he befriends), as will be explored in the final section. An 'ethics of care' comes to the fore in Bariloche which, as Lawrence Buell has proposed, is a feature of environmental care. $^{23}$

${ }^{23}$ Lawrence Buell, The Future of Environmental Criticism (Malden, MA; Oxford: Blackwell, 2005), p. 20. This 'ethics of care' has been propounded by ecofeminists, 
I will now turn to examine the way in which waste materials are narrated in Neuman's fragmentary novel, that is, to explore the ways in which the narrator weaves them into the fabric of the story - in particular the story of Demetrio that is reconstructed throughout the novel, recovered from the rubbish dump of memories. As we shall see, Demetrio's relationship with the rubbish that he collects is to a great extent connected with his relationship with his past: one of nostalgic sentimentalism. Fragmentary discarded objects are used by the main character as material triggers that revive his ghostly memories, and by the author to link together the two narrative strands that constitute the novel: Demetrio's past in Bariloche and his present in Buenos Aires. Since waste materials are inherently fragmentary, dislocated from their original location and purpose, they can easily be reappropriated, recontextualized and reconfigured. Their residual quality as present remainders and reminders of the past allows character and narrator alike to weave fragmentary memories into the narrative. According to Zygmunt Bauman, the 'heroic' role of the rubbish collector is to refresh and make salient again the borderline between normality and pathology, health and illness, the desirable and the repulsive, the accepted and the rejected, the comme il faut and comme il ne faut pas, the inside and the outside of the human universe. That borderline needs their constant vigilance and diligence because it is anything but a 'natural frontier' [... It] is drawn afresh with every round of garbage collection and removal. ${ }^{24}$

\footnotetext{
since it is especially associated with women, who as Buell suggests 'are culturally if not biologically constructed to undertake [care] more readily than men.' (p. 20) ${ }^{24}$ Bauman, Wasted Lives, p. 28.
} 
Demetrio's habit of 'dissecting' the bags and going through the rubbish, of 'indag[ar] en las bolsas con meticulosidad' (p. 24), undermines the equation of waste with 'lo caducado o lo ya inútil, roto, desdeñado, sustituido' (p. 142), the notion that waste is meaningless and worthless. By rupturing the black, plastic seal that separates the rubbish from view and attention, by delving without disgust into the bags' contents, he blurs the borderline between the desirable and the repulsive, the worthy and the worthless. The first object that he separates from the refuse is a doll with red hair: 'los guantes de Demetrio sostenían una pequeña cabeza pelirroja, un torso sin brazos y una pierna izquierda que, descoloridos, aún evocaban cierta antigua morbidez' (ibid.). Like the memories that allow him to retrieve his past, the doll is fragmented, dismembered, and faded. Yet it still retains material traces of the past, particularly the tactile quality of softness. Rather than an indifference towards, or detachment from, the waste object, the language used to describe it evokes affection, care and attachment. Even El Negro, who views Demetrio's actions of delving into the waste with respectful incomprehension, gazes at 'la piernecita, el torso minúsculo' (p. 25). The diminutive suffix and the adjective 'miniscule' convey affection, turning the discarded doll into an object of sentimental value. Demetrio finally restores value to the doll through an ad hoc death shroud, by wrapping its parts together in orange peel.

The doll, beyond the immediate narrative of Bariloche, is also reminiscent of the dictatorship's many ways of disposing corpses. Correspondingly, her depiction by Neuman has elements of other post-dictatorship works of art, most notably in 1980s' and 90s' cinematic production of directors like Fernando Solanas (Sur, 1988) and Eliseo Subiela (Hombre mirando al sudeste, 1986), in the work of visual artists such as León Ferrari (Nunca más, 1995-96, and Brailles, 1994-c. 2004), and literary works 
by the likes of Néstor Perlongher. These works, in different media, share certain formal features, most notably an aesthetics of fragmentation and withdrawal which reproduces the theme, context, or background of forced disappearances. Though this context and subtext cannot, for reasons of space, be explored fully within this article, the echoes between Neuman's work and that of his Argentine forebears and contemporaries can be illustrated in the following passage from Perlongher's epic poem Cadáveres (1987):

\section{$[\ldots]$ en la}

humedad de esas bolsitas, bolas, que se apisonan al movimiento de los de Hay Cadáveres

Parece remanido: en la manea de esos gauchos, en el pelaje de esa tropa alzada, en los cañaverales (paja brava), en el botijo de ese guacho, el olor a matorra de ese juiz

Hay Cadáveres $[\ldots]^{25}$

Throughout this highly charged poem, the recurring refrain 'Hay Cadáveres' is followed by a cumulative, diverse and ambiguous list of locations, objects, characters, and so on. Various elements prefigure Neuman's Bariloche, most notably the fragmentary, repetitive structure characterized by ellipses and omissions, suggesting melancholic and obsessive attachments to the past and the dead, as well as the experience of trauma; and the use of the four senses (sight, touch, smell and taste are

${ }^{25}$ Néstor Perlongher, 'Cadáveres', in Prosa plebeya. Ensayos 1980-1992 (Buenos Aires: Colihue), p. 229. 
invoked in many of the images and references, including 'humedad de esas bolsitas', 'pelaje', 'paja', 'botijo', 'olor a matorra', and of course in the leitmotif 'cadáveres').

Although the dictatorship is not the immediate context of Neuman's novel, the ghosts, scars and traumas of post-dictatorship Argentina linger in the background of Bariloche. The discarded red-headed doll adumbrates the figure around whose absentpresence the narrative will gravitate: Demetrio's 'diosa pelirroja' (p. 32), the maddening redhead of his childhood memories and adult fantasies. Her dismembered limbs - an armless torso and a single leg - prefigure, and in a sense configure, the narrative fragments in which the ghost of the redhead makes fleeting appearances, as 'una figura hermosa, obsesionante' (p. 51); as 'el espectro de una figura hermosa y obsesionante lo perseguía' in his frustrated adult dreams (p. 59); as 'la espectral figura de perfil sombrío, hermoso y obsesionante' that appears and disappears in Demetrio's jigsaw puzzle (p. 75). The material object found in a bin liner is therefore metamorphosed into a recurring narrative strand, which not only revives Demetrio's memories, but also draws the reader into different spaces, whether the Bariloche of Demetrio's childhood or the Bariloche of his jigsaw puzzles; whether Demetrio's teenage fantasies or his adult dreams. In fact, the whole novel could be seen as the narrativization of Demetrio's vain attempt to return to one particular point in space and time, the morning of the 'definitive' kiss with his childhood sweetheart: 'fue esa madrugada cuando más pasión sentí, y desde esa vez mi vida va así medio limosneando cachitos de ese sentimiento' (p. 64). A beggar to his own past, it is in the waste bin that he is able to recover shreds of this passion. His affective response to the doll is a tiny shard of a feeling that is otherwise inaccessible to him.

The only discarded object that Demetrio takes home with him, though, is an old pair of boots, which are first presented to the reader thus: 
Demetrio abrió la guantera del camión y sacó dos deformes trozos de cuero áspero con una cremallera vertical en los costados. ¿Y eso qué mierda es, Demetrio? Demetrio le acercó las botas a la cara para que las viera mejor, y el Negro se encogió de hombros. (p. 29)

The reader is thus offered different perspectives. El Negro's response to the refuse is one of disdain (conveyed by the word 'shit') and indifference (implied by the raising of his shoulders). Demetrio, on the contrary, by rescuing the boots from the detritus and showing them to El Negro, reendows them with value. Holding them up close to his workmate's face, he overturns the invisibility and distance of waste, hidden as it normally is by black plastic bags and placed far from view. This passage therefore further dissolves the barrier between included and excluded, between redundant, worthless, repulsive waste and useful, valuable, desirable object.

In fact, Demetrio's fantasies - and therefore the narrative which (re)counts and (re)constructs them - are fuelled by the fertile ambivalence of the line between waste and non-waste, past and present, decaying and living. The boots are revived through his actions and thoughts: 'les pasó betún, mientras imaginaba que estaba acariciando el lomo de algún potro exhausto, creyendo escuchar cómo los poros iban refrescándose con la humedad del ungüento hasta saciarse' (p. 131). The rejected boots are given careful treatment by Demetrio, polished less like footwear than like old silverware, like a valuable object, a collector's item. This activates an 'ethics of care' that is both inward-looking (as he is gazing back into his own personal history) and outward-looking (since he is enacting an environmental 'ethics of care'). Neuman's depiction of this caring attachment to a rough old pair of boots chimes with 
Van Gogh's still life painting of a real pair of coachman's boots he bought at a flea market: Pair of Shoes (1886, Oil on Canvas). As Dieter Beaujean notes, he began his study for this painting after returning from a long walk in the rain and the mud to create the worn, tattered effect that he achieved so masterfully. ${ }^{26}$ An interesting supplement to the painting is Van Gogh's statement that 'Dirty shoes and roses can both be good in the same way, ${ }^{27}$ which not only underlines the ephemeral beauty of both, but also blurs the line between dirty, disgusting, decaying and discarded things and clean, beautiful, living and valuable objects.

Through Demetrio's imagination, the boots are revived as an exhausted foal, a young animal. The tactile and visual senses are combined with the auditory, as the protagonist seems to hear the pores of the leather absorbing the polish, 'drinking' it like a thirsty living creature. As palpable objects, they produce a material link with a past from which the protagonist is otherwise severed, taking him back to the Nahuel Huapí lake where he used to wade in his black boots (p. 31). Though his old boots were made of rubber rather than leather, his affective attachment to the salvaged pair is transformative: they are severed from their own origins and even from their own material qualities, and recontextualized through Demetrio's personal history. Like the baseball in DeLillo's Underworld (1998), they allow him to 'reassemble a crucial moment in time out of patches and adumbrations' ${ }^{28}$ Though he does occasionally wear the boots around his flat, their value certainly transcends their original function. They trigger memories and sentiments, thus demonstrating what O'Brien terms 'the

\footnotetext{
${ }^{26}$ Dieter Beaujean, Van Gogh: Life and Work (Cologne: Konemann, 2000), p. 35. ${ }^{27}$ Ibid.

${ }^{28}$ Don DeLillo, Underworld (London: Picador, 2011), p. 181.
} 
meaningful personal relationships that people invest in the "junk" of their lives'. ${ }^{29}$ Whereas their previous owner had rejected them as old, damaged or useless, Demetrio becomes obsessed with them: in fragment XIII, he lies in bed, 'contemplando con el rabillo del ojo las botas negras' (p. 44); in fragment XVI, he gets up, 'procurando ignorar las botas negras' (p. 48); and in fragment XX, he puts them on only to sit at the table composing his jigsaw (p. 58). They are fetishized as objects that might somehow give him access to his own past.

On this level, waste is a narrative device used to connect the two strands and settings of the novel, the urban and the rural, Buenos Aires and Bariloche. It is not surprising, then, that it is on the rubbish dump that the different narrative strands - the horrendous cityscape of the landfill site and the idyllic landscape of the Patagonian lake district - finally come together. As Demetrio walks towards the rubbish dump in the dark, it seems to morph into the Nahuel Huapí of his childhood:

En medio de la noche recién venida le pareció oír un rumor como de agua golpeando piedras, pero se puso a escuchar mejor y se dio cuenta de que era una máquina removiendo toneladas de basura, o quizá nada, sólo el gruñido general de la ciudad allá abajo, tendida como una bestia demasiado indolente. (p. 165)

On the dump, the sources of sound become confused: the sound of a machine is connected with that of flowing water; the humdrum of the city is linked to the growling of a lazy animal. At the end of the novel, the intensification of the natural

${ }^{29}$ O'Brien, A Crisis of Waste?, p. 8. 
imagery is such that the two spaces that produce the counterpoint of the narrative finally meet. Gradually, the rubbish dump turns into the Nahuel Huapí lake in the protagonist's imagination and the narrative's imagery:

un mar, ¿no era eso? O un lago prehistórico de nombre imposible, y la noche iluminó con lenta luz la superficie del Nahuel Huapí, olía a humedad, a piedra, la tierra oscura cedía y emanaba, el cielo y el lago se gruñían como dos osos rivales, infinitos, el frío endurecía los colores. [...] Había un algo como de pétalos caídos sobre un sendero embarrado [...] Le pareció que los destellos de los cristales habían sido un engaño: las estrellas, eran estrellas sobre el lago como espuelas que flotaban [...] y junto a la orilla de pronto ella, el camisón hecho jirones y la piel gastada como un nylon viejo. (p. 167)

The two narrative strands thus become inseparable: the growling of the city merges with the growling of the lake and sky of Bariloche; the dampness of the rubbish dump underfoot and the cold of the night blend with Bariloche's cool, humid climate; the decaying waste becomes a muddy lakeside path covered in fallen petals; the glistening shards of glass turn into stars reflected in the lake; the plastic bin bags become the redhead's skin; the shreds of paper and plastic on the dump metamorphose into her tattered nightshirt. The opposition between the ugly and the beautiful, the grotesque and the sublime, the city and the country is thus decidedly dismantled. Hence the final fragment, the lyrical depiction of Bariloche which also functions as a kind of epitaph to Demetrio, is filled with echoes of the cityscape. The chirping ('crujir') of the crickets evokes the mechanical creaking of the machines; the gleaming fireflies reminds the reader of the glistening shards of glass; the vibration of the myrtles recalls 
the pulsations of the waste dump; the humid scent echoes the 'húmeda vaharada' of Buenos Aires with which the reader is greeted on the first page; and the sinking of the earth into the stony bank recalls the sinking of Demetrio's body into the 'body' of waste.

\section{'Collective, like Society’: Waste, Society and Environmental Injustice}

So far, we have looked at two aspects of the network of waste in Bariloche, its natural, bodily, biological processes and its constructed, narrative quality. In this final section, I shall turn to examine a crucial third strand with which it is inextricably connected: the socio-political. An essay by John Berger about the politics behind the life and work of the Italian poet Giacomo Leopardi (1798-1837) underpins the novel, and is present in fragmentary form in the epigraph, 'Así es como sobreviven los agotados' (p. 11). As Neuman explains, the novel first came into his mind when reading Berger's essay, which argues that 'la explotación suele pasar inadvertida para los explotados porque estos, demasiado cansados y hambrientos tras la dura jornada, encuentran una traicionera fuente de bienestar inmediato en la alimentación y el sueño $\cdot{ }^{30}$ Because the worker expends so much energy in the productive process, the body calls for food and rest. As Berger puts it in said essay, 'this need is so acute that, when it is satisfied or partly satisfied, the satisfaction, however fleeting, produces a hope for the next break'. ${ }^{31}$ The disillusion caused by the false promises made in the name of 'Progress' is temporarily relieved by ephemeral hopes and pleasures.

\footnotetext{
${ }^{30}$ Neuman, 'Basura, lengua y fragmentos' (2007).

${ }^{31}$ John Berger and Geoff Dyer, 'Leopardi', in Selected Essays (New York: Vintage, 2003), 453-58 (p. 457).
} 
Demetrio's hunger and tiredness are a recurring motif throughout the novel (pp. $21,37,58,156$, etc.). In fragment IV, for example, he is overcome by hunger and tiredness during his round: 'el sueño le emborronaba a Demetrio el pavimento [...] sentía de nuevo un pozo en el estómago' (pp. 20-1). His state of exhaustion and hunger is such that he does not reflect on his current state and condition, but rather fantasizes about his dinner, which awakens his senses of touch, taste and smell: 'patatas al horno, unos frescos tomates llenos de rojo, un filete jugoso y hasta obsceno, luego zambullirse en la cama, restregar el rostro, los muslos contra las sábanas, sonreír extenuado; luego la inconsciencia' (p. 21). The sensuousness of the language, with its assonance and sibilance, reproduces in the reader the seductive, deceptive pleasures of the experiences of eating and sleeping. Caressed by the immediate effect of the words in the same way as Demetrio's mind is calmed as he returns to his apartment to rest, the reader is lured into the trap identified by Berger.

In what follows, I shall examine the socio-political subtext of the novel. A clue can be found in another comment made by the author himself: 'unos producimos mierda sabiendo que otros cargarán con ella' ${ }^{32}$ Those who produce most waste do not have to deal with it, get rid of it, remove it from sight, or suffer from its toxicity. The term 'other' here is doubly significant: not only does the responsibility for waste disposal fall on people 'other' than those who produce it, but this divide also produces others, otherness, exclusion; it turns those in charge of, or associated with, waste (whether cleaners, sweepers, waste collectors, or scavengers) into social others, into marginalized, rejected subjects.

\footnotetext{
${ }^{32}$ Ibid.
} 
Mary Douglas pre-empted this social situation in her now classic Purity and Danger (1996), where she insists on the constructedness of dirt - and therefore waste by extension. As she insists, 'there is no such thing as absolute dirt: it exists in the eye of the beholder'. 33 'Dirt', she argues, is not inherent but rather 'matter out of place', and is therefore the fruit of 'symbolic systems' ${ }^{34}$ Sarah Moore puts these ideas into a contemporary socio-political context in her recent case study of the Mexican town Oaxaca's waste dump in Environmental Justice in Latin America. 'The desire for clean and modern environments,' she writes, 'means that garbage and those associated with it must be erased from the landscape. However, as this process of purifying the city is never complete, remnants threaten the integrity of the (social) body'. ${ }^{35}$ This process of social construction through social exclusion becomes evident in Demetrio's experience on Avenida Corrientes, which in his eyes is characterized by its 'brillo', its ever more gleaming twenty-four hour shops, its elegant passers-by in their shiny Mercedes and BMWs and new, expensive coats (p. 84). The passage gives a heightened awareness of the desire for superficial cleanliness and sterility paradoxically associated with an accentuated consumerism that produces constant surplus, refuse and pollution. It foreshadows the question posed by Bauman in Wasted Lives: 'are we not the ones, the rich, the carefree consumers of the planet's resources,

\footnotetext{
${ }^{33}$ Mary Douglas, Purity and Danger: An Analysis of Concept of Pollution and Taboo (London and New York: Routledge, 1966), p. 2.

${ }^{34}$ Ibid., p. 35.

${ }^{35}$ Sarah A. Moore, 'Waste practices and Politics: The Case of Oaxaca, Mexico', in David V. Carruthers, Environmental Justice in Latin America: Problems, Promise, and Practice (Cambridge, MA: The MIT Press, 2008), 119-136 (p. 133).
} 
who are the true planetary "parasites", "scroungers" and "spongers"?'36 The shiny façade of consumerism, as Neuman and Bauman demonstrate, is achieved by handing its darker underside onto others, by calling upon others to carry out the dirty work that will enable its perpetuation.

The paradoxical desire for cleanliness that accompanies wasteful lives is demonstrated by the pedestrians' smell of cologne, disguising any undesirable odours produced by sweat (another form of bodily excretion). It is also manifest in the extinction, as the narrator points out, of certain businesses from the avenue, notably 'las sucias librerías de segunda mano, con su olor a página chamuscada y a polvo’ (p. 84). The cityscape therefore lays bare the process of purification, as the older shops specializing in second-hand goods - characterized by their dirty appearance and dusty smells - are cleared away, leaving room for the new, the shiny, the clean. Avenida Corrientes as viewed through Demetrio's gaze is an emblem of what Martin O'Brien terms a 'rubbish-free sensibility':

From shiny new cars to shiny new towns through which to drive them, a rubbish-free sensibility has infested the modern world's outlook on life. This sensibility is a mask or, more appropriately, a cloak that has been worn as ideological protection from what waste really represents and really underpins in contemporary society. ${ }^{37}$

\footnotetext{
${ }^{36}$ Bauman, Wasted Lives, p. 44.

${ }^{37}$ O'Brien, A Crisis of Waste?, p. 4.
} 
By draping themselves in brand new coats, driving expensive new cars, and spraying themselves with cologne, the porteños mask the grimy underside of their consumerist lifestyles. Yet this underside is visible in the image of Corrientes Avenue's 'larguísimo tigre bicéfalo: en oro y gris oscuro, discurrían de un lado las hileras envueltas en cuero, pana, pieles; del otro lado, cuerdas y cuerdas de siluetas sucias, silenciosas' (p. 84). The colour-based opposition constructed by the narrator is between the shining, polished gold and the dirty, murky grey. Contrasting stripes on the same beast, the one is inextricable from the other. And as indicated by the 'reproche airado' received by the grey beings as their paths cross with those of the golden beings (ibid.), this polarity is not natural, but man-made, produced by social attitudes as well as economic structures.

This social segregation might be considered in the context of the social and political thought of Zygmunt Bauman, who argues that modern capitalist society produces 'wasted lives': the unemployed, the asylum seeker, the beggar, or the migrant who lacks the skills or means to participate in labour and consumer markets and therefore becomes marginalized from society, inheriting the properties of waste materials, of things deemed 'useless' and disposable. ${ }^{38}$ To be 'redundant', he notes, means to be supernumerary, useless, disposable. He quotes Danièle Linhart, who asserts that being made redundant is much more than financially debilitating, since people 'find themselves stripped of their dignity as workers, of self-esteem, of the feeling of being useful and having a social place of their own' ${ }^{39}$ This echoes the point made by Berger in the essay that inspired the novel: 'work, because it is productive,

\footnotetext{
${ }^{38}$ Bauman, Wasted Lives, pp. 12-13.

${ }^{39}$ Ibid., p. 13.
} 
produces in man a productive hope. Hence one of the reasons why unemployment is so inhuman. ${ }^{40}$ And hence El Negro, in Bariloche, affirms that 'el laburo es lo más importante queay cinco veces por semana, sí señor' (p. 89), and Demetrio’s father becomes ill after losing his job at the sawmill. 'No fue la plata [...] lo que lo hizo enfermarse' (p. 107), the narrator pointedly remarks. The implication is that, as Linhart puts it, it is his loss of self-esteem that leave him deflated and empty, signalled in the way he sits 'postrado en la silla' (ibid.) and gazes fixedly with a 'mirada vacía' (p. 114). The psychology of the 'wasted life' is also hinted at by his angry, dismissive reaction to his wife's suggestion of going to work herself: 'había soluciones que no eran soluciones porque herían la dignidad' (p. 108). First and foremost, then, it is his sense of dignity that is damaged by his unemployment.

The most explicitly 'wasted life' in Bariloche, however, is that of 'el viejo de Tacuarí', the tramp to whom Demetrio develops a strange attachment and who in some ways foreshadows the figure of the Organ Grinder in Neuman's more recent $E l$ viajero del tiempo (2009). ${ }^{41}$ Neuman encourages the reader to connect his state with that of the unemployed father by repeating the word 'dignity' in the subsequent fragment: when Demetrio offers to take the tramp to the rubbish dump to scavenge on its humble offerings, 'era la dignidad del viejo lo que le impedía ir' (p. 109). Unlike Demetrio's father, though, the tramp's destitution brings him into direct contact with

\footnotetext{
${ }^{40}$ John Berger and Geoff Dyer, 'Leopardi', p. 457.

${ }^{41}$ This character, like 'el viejo de Tacuarí', is a solitary old tramp who suffers from isolation and alienation. Unlike 'el viejo', though, the Organ Grinder lives not in the city, but rather in a cave in an idyllic rural environment. See Andrés Neuman, $E l$ viajero del tiempo (Alfaguara, 2009).
} 
garbage. He came to Tacuarí, as the narrator puts it, in order to find 'buena basura' ( $\mathrm{p}$. 93). Feeding off the waste of others, he gathers whatever he can lay his hands on. When Demetrio buys him a coffee, he keeps the spoon and sugar sachet for future use instead of using or discarding them (p. 94). Significantly, his entire physical being takes on the qualities of garbage:

el sombrero, alguna vez de fieltro, de coloración incierta, retenía un tufo a soga vieja proveniente de la mata de cabellos. Era cierto, también, que sus dedos eran apéndices de mugre, negruras con falanges que lo tocaban todo con fruición de manos vacías. (pp. 93-4)

Everything about him is reminiscent of rotting discards: his foul stench is likened to that of an old rope; his clothes are tattered and weathered; he has filthy hair and hands. This is reinforced by the terms used to denote the tramp in the novel 'andrajoso' (p. 93), 'harapiento' (p. 94) and 'zaparrastroso' (p. 105) - which connect the old man's being with rags, with tattered clothes. Like the waste object, el viejo is rejected and scorned. This is echoed by El Negro's dismissive attitude toward him, shown by his condemnation of Demetrio's acts of kindness towards him: ‘lo del zaparrastroso ese nunca me gustó' (ibid.). It is also implied by the way in which Demetrio asks himself, ‘Cómo sería vivir entre los desperdicios, ser uno más de ellos?' (p. 110) The pronoun 'ellos' is ambiguous: grammatically, it could refer to the scavengers, the social others produced by the capitalist system, the rejects that 'scrounge' off the waste of others; or to the 'desperdicios', the refuse itself. This ambiguity is significant, and foreshadows Bauman's attribution of the properties of waste materials to the people who, like the rubbish off which they live, represent 'lo 
ya inútil, roto, desdeñado, sustituido' (p. 142); to those who do not contribute to the productive, market-driven goals of the capitalist machine.

Finally, the refuse collectors in Neuman's novel might also be regarded as 'wasted lives', in the sense that they are treated by other city-dwellers as a surplus, an undesirable, albeit necessary, excess. This becomes evident in the narrator's reflection that, towards the end of their round, 'la ciudad comenzaba a echarlos [a Demetrio y al Negro]. Como intrusos fosforescentes, recogían las últimas bolsas con un vago sentimiento de pudor que jamás habían comentado' (p. 142). The collocative meaning of the verb 'echar' - connoting rubbish - suggests the transformation of the waste collectors into the city's discards. Consumer society, in its desire to turn a blind eye to the ugly underside of its shiny, clean veneer, treats the rubbish collector as another form of waste. 'Phosphorescent intruders', they metamorphose into their work clothes as their identity is subsumed by their lowly profession; they lose their agency as social subjects and become rejected objects, become waste. It is significant, in this sense, that Demetrio - in expressing to El Negro his desire to quit his job - repeats the expression 'estar podrido de [juntar la basura]' (pp. 89, 118-9). In its figurative sense, this phrase means 'to be fed up with', but what it conjures for the reader in the context of a book gravitating around themes and images of garbage is its literal meaning of 'being rotten'. Like the 'viejo de Tacuarí', the character of Demetrio is connected with waste through an image of decay and decomposition.

It is therefore not just the waste materials, as shown in the previous sections, which take on real or imagined human forms, but also the human subject that takes the form of the waste. Demetrio's inner self becomes a reflection of the rubbish with which he works, a product of a society that requires 'wasted lives' to perpetuate itself. Within this socio-political strand of the 'network' of waste, the ending is the 
culmination of this process. Demetrio's grotesque communion with the waste dump is a literalization of the merging of human subject and wasted object: 'por fin aquel cuerpo de papiros se fue hundiendo lentamente entre las bolsas con un ruido a máquinas y a lodo' (p. 167). The moment his ankles sink into the 'body' of waste might therefore be interpreted as the culmination of what Bauman terms the 'meeting of human rejects with the rejects of consumer feasts' ${ }^{42}$ His literal sinking into the waste dump, which suggests and adumbrates his suicide, is also a metaphorical dive to the bottom and the edges of society, a final act of becoming waste.

\section{Conclusions}

This article has drawn attention to the different aspects of waste in which the characters are entangled in Neuman's Bariloche: real (as a set of materials involved in biological, chemical processes and trans-corporeal exchanges), narrative (as a collection of fragments and residues on which memories and stories are (re)constructed) and collective (as associations of excluded humans and discarded materials). As I have argued, these threads form what Latour terms a 'network', a set of processes that cannot be categorized as natural or cultural, that cannot be viewed exclusively as scientific or social phenomena. The network of waste in Bariloche therefore emblematizes the 'proliferation of hybrids' that for Latour characterizes modern society, and that for environmental critics undermines the constructed - and dangerous - divides between the human and more-than-human world.

\footnotetext{
${ }^{42}$ Bauman, Wasted Lives, p. 59.
} 
In a sense, this network is adumbrated by the hybrid paratexts of the novel: the extract from a highly political essay by Berger (cited above); the quotation from a literary text by Joseph Conrad ('Vivimos igual que sonamos: solos.'); the lyrics from the tango song 'Sur' by Homero Manzi ('Nostalgia de las cosas que han pasado,/ arena que la vida se llevó,/ pesadumbre de barrios que han cambiado,/ y amargura del sueño que murió.'); and the scientific reference to Bariloche's geographical features ('Bariloche: c. emplazada sobre la orilla merid. del lago Nahuel Huapí, prov. De Río Negro, $41^{\circ} 19^{\prime}$ lat. S, $71^{\circ} 24^{\prime}$ long. O. Limítrofe con prov. De Neuquén. Estación sismográfica. Accid más imp.: cerro Catedral y monte Tronador.'). The literary and musical references (both in terms of their narrative form and in their content referring to the experiences of life, loneliness, nostalgia, temporality and mortality) are narrative and discursive, but also refer to material - real, 'natural' - processes of decay and death. The geographical and geological description seems to represent reality, 'nature', yet as soon as we delve below the surface of the words, numbers and symbols, this materiality is belied, and the geographical locations are invaded by people, ideas and ideologies. The latitude and longitude measures relate to imaginary lines traced around the earth and the names relate to the ways in which people have used or imagined the landscapes: the name Bariloche derives from the Mapuche word Vuriloche, which refers not to the area itself, but to the "people from behind the mountain",;3 Nahuel Huapi, in the Mapuche language, means jaguar island, perhaps simply because there used to be jaguars there, or perhaps because they formed part of

\footnotetext{
${ }^{43}$ See <http://bariloche.com/ciudad> [last accessed: 20 January 2014].
} 
Native American imaginary and symbolism $;{ }^{44}$ and one of the principal mountains is imagined as a cathedral, an example par excellence of the man-made as an architectural expression and monumentalization of Christian beliefs.

It is the ending that brings together the strands of the narrative and the components of the network. Demetrio's (or the red head's) 'cuerpo de papiros' connect the human body with the leaves of Bariloche's trees, described earlier as 'hojas diminutas, papiros aromáticos' (p. 45), but also suggest the paper on which the narrative - Demetrio's story, Neuman's book - itself is written, and the fragility and disposability of the 'wasted life'; the sound of the sinking body is both industrial and natural, linking the droning machines of Buenos Aires's waste dump with the squelching mud beside the Nahuel Huapí lake.

It might be argued that this interpretation goes against Neuman's own vision of his novel, which he describes as a 'novela para armar'. 'Cada fragmento', he affirms, 'debía evocar la parcialidad de una pieza, el ritmo progresivo de un puzzle. Mientras iba ordenando los distintos planos de la novela, comprendí que en realidad toda ella era un puzzle. ${ }^{45}$ Undoubtedly, the fragmentary, non-chronological form of the novel, divided as it is into short fragments that have to be recomposed in the reader's mind, is a structural reproduction of the jigsaw puzzles which, throughout the text, are used by Demetrio to access his past, and by Neuman to link the narrative of Demetrio's present reality in Buenos Aires with his nostalgic and idealizing reveries

\footnotetext{
${ }^{44}$ Adrian Room, Placenames of the World: Origins and Meanings of the Names for 6,600 Countries, Cities, Territories, Natural Features and Historic Sites (McFarland, 2006), pp. 260.

${ }^{45}$ Neuman, 'Basura, lengua y fragmentos' (2007).
} 
about his past in Bariloche. Yet as we have seen, certain strands cut across these fragments that lead the reader to assemble not only a 'puzzle', where each piece slots in perfectly and tessellates with the others, but also a much messier network in which the threads intersect and collide; in which nature, narrative and society interact in complex processes of mutual transformation; in which waste becomes human and humans become waste. 
University of Surrey

Lucy Bell

Lucy Bell

School of English and Languages

University of Surrey

Guildford

GU2 7XH

1.a.bell@surrey.ac.uk 